\title{
ГУМАНИСТИЧЕСКИЙ ПОДХОД К ВОСПИТАНИЮ ДЕТЕЙ В ДОШКОЛЬНОМ УЧРЕЖДЕНИИ И ПРАКТИЧЕСКАЯ ПСИХОЛОГИЯ В ДЕЙСТВИИ
}

\author{
Е. Ю. Проненко \\ Московский гуманитарный университет
}

\begin{abstract}
Аннотация: В статье рассмотрены проблемы, возникающие при неправильном антигуманном подходе к воспитанию детей дошкольного возраста в детском саду и его травматизирующее воздействие на развитие ребенка, его психологическое состояние.

Ключевые слова: гуманизм; гуманистический подход; воспитание ребенка; требования к воспитателю; психология отношений; межличностные отношения
\end{abstract}

\section{HUMANISTIC APPROACH TO EDUCATION OF CHILDREN IN PRESCHOOL AND PRACTICAL PSYCHOLOGY IN ACTION}

\author{
E. Y. Pronenko \\ Moscow University for the Humanities
}

\begin{abstract}
The article considers the problems arising from the wrong, antihuman approach to education of preschoolers in kindergartens and its traumatizing impact on the child's development and their psychological state.

Keywords: humanism; humanistic approach; child education; requirement to the tutor; psychology of the relations; interpersonal relations
\end{abstract}

Любовь и гуманизм по отношению к ребенку - это блажь или необходимость? В своей работе Я. Корчак рассказывает, что означает любовь и уважение к ребенку, духовность, доброта и милосердие (Корчак, 2014). Работая в детском саду и столкнувшись с реальным проявлением этих основополагающих норм в отношении, как к детям, так и к воспитателям, я была, мягко говоря, удивлена. Из уст администрации я услышала слова, произнесенные на педсовете ипобудившие меня к написанию этой статьи: «Дети должны убирать игрушки каждые пятнадцать минут!» Сразу возник вопрос: «Зачем?» Последовал ответ: «Пусть учатся дисциплине». Создается ощущение, что мы находимся не в детском саду, а в армии, где командует и отдает приказы генерал. В этом конкретном случае сложно говорить о гуманистическом подходе. Работая в дошкольном учреждении в средней группе с детьми 4-5 лет, я наблюдаю изо дня в день проявление так называемого «гуманизма». 
Гуманистический подход, как мы помним, характеризуется следующими принципами: ценность человека и его переживаний по отношению к себе и другим; поддержка и стимулирование развития творческих способностей; признание достоинства человека, его потенциалов и возможностей рота и самореализации.

Заставляя ребенка убирать игрушки каждые 15 минут, разве мы стимулируем его развитие, проявляем уважение к нему как к самоценной личности? Мы просто пытаемся им манипулировать, проявляя свои садистские наклонности. Об этом писал Э. Фромм, характеризуя авторитарную личность (Фромм, 1989).

Гуманистический подход подразумевает принятие человека, в нашем случае - ребенка, таким, какой он есть, со всеми его достоинствами и недостатками. Принять, а не оценивать, тем более, не осуждать - важнейший принцип гуманистических отношений.

Как пишет М. Швейцар, из воспоминаний детства в памяти остаются и яркие моменты, например, праздники и подарки, и травмы, которые впоследствии мешают нормальной жизни. Причем, травмы зачастую не вспоминаются, а с помощью защитных механизмов, например, таких как вытеснение, стираются из памяти и уходят в бессознательное и т. д. (Швейцар, 2003).

Напомним, что семейный климат и отношения в семье - ближайшем социальном окружении ребенка - влияют на его психическое состояние и развитие. Конечно, в каждом детском саду, точнее, в каждой группе, есть «проблемные» дети. И именно им нужны, прежде всего, помощь психолога, поддержка и понимание со стороны воспитателя. А что такой ребенок получает?

В нашем случае в качестве примера выступает 4-летняя девочка Д. Ей, к сожалению, не повезло с ближайшим окружением; у девочки существуют проблемы во взаимоотношениях с родителями. В семье по отношению к ребенку применяются физическое насилие, различного роды угрозы, наказания в виде лишения удовольствий, выставления ребенка за дверь и т. д. У девочки отсутствует чувство безопасности и защиты. Каковы же следствия такого воспитания? Появляется желание угодить маме и остальным членам семьи, чтобы стать любимой дочкой, постоянный страх быть наказанной. У девочки уже проявляются мазохистские наклонности. Пребывая в детском саду, Даша ожидает уже ставших, привычными для нее наказания, порицания. Больно смотреть на такого ребенка, и есть огромное желание помочь ему. Но, к сожалению, без участия ее семьи этосделать невозможно.

Что же мы видим, наблюдая за работой педагога по физкультуре? Д., как бы «выпрашивая» очередную порцию наказаний, получает ее. Педагог постоянно ее стыдит перед группой, постоянно выводит из зала и сажает 
отдельно, т. е. реализует по отношению в ней те формы воздействия, которые ребенок ожидает и хочет получить от взрослого человека. Где же здесь проявление гуманизма педагога, любовь и уважение к ребенку, знания психологии и педагогики? По сути, педагог реализует ту же воспитательную стратегию, которой придерживаются родители, еще более травмируя ребенка и закрепляя его негативные наклонности и черты характера.

В своей книге «Воспитание ребенка» М. Швейцар пишет о таком методе воспитания, как поощрение и наказание. При этом он указывает, что холодность и физическая расправа унижают ребенка, ломают его психику, вызывают чувство стыда, но не учат ребенка самодисциплине. Наоборот, такой ребенок при родителях бывает послушным, а в другом месте становится совершенно не управляемым. Чувство вины, которое испытывает ребенок, регулирует его поведение. Но постоянное ощущение вины непременно приведет к снижению самооценки и самоуважения ребенка, лишит его стимулов для личностного роста (Швейцар, 2003).

Понятно, чем руководствуются родители и воспитатель, формируя и поддерживая чувство вины у ребенка - создание условий для более успешного манипулирования маленьким человеком, подчинение его себе, лишение его собственной воли.

М. Швейцар особо подчеркивает важность сопереживания родителей поступкам и чувствам ребенка. Наглядный пример из практики. Ребенок нарисовал рисунок или слепил подделку. Мама, забирая его вечером из детского сада, проявляет равнодушие к восторженному рассказу ребенка о его успехе, не разделяет с ним его радость. Тем самым, по сути, ею наносится серьезный удар по самооценке ребенка, его самоуважению, уверенности ребенка в своих силах. И главное - разрывается эмоциональная связь матери и ребенка, на которых базируются чувства доверия, уважения и любви в детско-родительских отношениях. Очевидно, что в очередной раз ребенок просто не захочет показать маме или папе то, что он сделал, а скорее всего, сработает защитная реакция, и он перестанет что-либо пытаться сделать.

Отношения с братьями и сестрами также являются важным моментом в воспитании детей. Какие чувства проявляют родители к старшим или младшим детям, и как это сказывается на развитии ребенка? Родители часто сравнивают детей, говоря им, что один красивее, другой умнее и т. д. При неадекватном распределении родительских чувств между детьми и открытом демонстрировании своих предпочтений у ребенка, обделенного вниманием и поддержкой со стороны самых значимых для него людей, могут формироваться комплексы, психосоматические расстройства, возникать чувства горечи, гнева, обиды и т. д. О трудностях и путях преодоления указанных негативных тенденций в личностном развитии 
человека писал А. Адлер (Адлер, 1995).

В группе детей, с которыми мне пришлось работать, у многих есть брат или сестра. Наблюдения показывают, что ряд детей имеет адекватную самооценку. Они не сравнивают себя с другими, не стремятся доказать свое превосходство, уверены в себе. Родители любят и уважают этих детей. Но есть и иные примеры - дети, которые постоянно пытаются сравнить себя с кем-то и постоянно испытывают обиду и горечь. Даже в разговоре с такими детьми можно услышать обиду в их рассказах о братьях или сестрах. К таким детям мамы относятся соответствующим образом. Забирая ребенка, как правило, к ним обращаются со словами: «Ну что тебе? Дома брат ждет, а ты тут копаешься? Какой же ты медлительный. Когда ты научишься быстро одеваться? С твоим братом у меня никогда не было проблем. Он всегда был первый» и т. д. Печально, когда и воспитатель совершает те же действия, что и родитель, давая негативную оценку личности ребенка при сравнении его с «лучшими», «более успешными», «более послушными» детьми. Ребенок, который дома не чувствует себя в безопасности, в принятии и любви, и в детском саду ощущает аналогичные чувства унижения, стыда, несправедливости, беспокойства. Ситуация похожа на замкнутый круг. Родители травмируют своих детей, а воспитатели и педагоги в детском саду помогают им в этом преуспевать.

Каковы же условия обеспечения гуманистического подхода к детям в дошкольном учреждении?

Первое необходимое условие - высокий профессионализм и психолого-педагогическая грамотность воспитателей. Я провела анализ по поиску вакансии воспитателя дошкольного учреждения. Во всех вакансиях одинаковые требования работы: без опыта и со средним образованием. Возникают огромные сомнения, что человек со средним образованием обладает квалифицированной подготовкой, чтобы знать психологические особенности ребенка и понимать его внутренний мир. А таких воспитателей в нашей стране большинство.

Вторая важная причина, по моему мнению, личностный опыт воспитателя. Первое правило психолога, прежде чем пойти работать: необходимо пройти собственную терапию, определенное количество часов. Почему от воспитателя этого не требуют? Его непосредственная работа состоит в общении, понимании, и умении находить общий язык с детьми, применяя методы воспитания, известные нам с давних времен. Воспитатель неосознанно может перекладывать разными способами свои личностные и психологические проблемы на детей. Либо как в нашем случае, садистские наклонности находят выход.

Следующей причиной я считаю количество детей в группе, которое не соответствует возможностям воспитателей. В группе обычно бывает 
30 детей и один воспитатель на смену. Как может один человек успеть найти общий язык со всеми детьми одновременно, успеть объяснить, поговорить, научить? Когда он успеет проявить гуманистический подход ко всем детям? Поэтому воспитатель поступает просто, используя манипуляторские действия и угрозы, чтобы просто усмирять детей. В данном случае очень сложно, да и практически невозможно говорить о гуманистическом подходе к детям, к сожалению.

Текущая ситуация в воспитании детей дошкольного возраста приводит к удручающим и порой плачевным последствиям. Какова цена дальнейшей жизни детей? Необходимо изменить требования к набору воспитателя в дошкольном учреждении. Научится применять знания психологии и педагогики вработе с детьми (Романюк, 2012; Ситаров, 2012; Учитывать индивидуальные особенности ребенка и делать акцент на них. И пытаться предотвратить травмы родительской «любви», помочь перестроится и наладить психологическую составляющую жизни.

\section{СПИСОК ЛИТЕРАТУРЫ}

Адлер, А. (1995) Практика и теория индивидуальной психологии. М.: За экономическую грамотность. 296 с.

Корчак, Я. (2014) Как любить ребенка. М. : АСТ.

Романюк, Л. В. (2012) Гуманистическая педагогика // Знание. Понимание. Умение. № 2. С. 304-307.

Ситаров, В. А. (2012) Ненасильственные технологии организации обучения и воспитания детей в образовательных учреждениях // Знание. Понимание. Умение. № 3. С. 261-265.

Фромм, Э. (1989) Бегство от свободы / пер. с англ., общ. ред. и послесл. П.С. Гуревича. М. : Изд-во Прогресс. 272 с.

Швейцар, М. (2003) Воспитание ребенка // Родители и дети: хрестоматия. Учебное пособие по педагогике / ред. Д. Я. Райгородский. Самара: Бахрах-М. 783 с.

Дата поступления: 08.12.2016 г.

Проненко Екатерина Юрьевна - аспирант кафедры общей психологии и истории психологии Московского гуманитарного университета. Адрес: 111395, Россия, г. Москва, ул. Юности, д. 5. Тел.: +7 (499) 374-6720. Эл. адрес: pronenko@mail.ru. Научный руководитель - д-р психол. н., проф. В. А. Кольцова. 
Pronenko Ekaterina Yurievna, Postgraduate Student, Department of General Psychology and History of Psychology, Moscow University for the Humanities. Postal address: 5, Yunosti st., Moscow, Russian Federation 111395. Tel.: +7 (962) 999-03-47. E-mail: pronenko@mail.ru. Scientific Adviser V.A.Koltsova, Doctor of Psychology, Professor.

\section{Для цитирования:}

Проненко Е. Ю. Гуманистический подход к воспитанию детей в дошкольном учреждении и практическая психология в действии [Электронный ресурс] // Научные труды Московского гуманитарного университета. 2017, № 1.URL: http://journals.mosgu. ru/trudy/article/view/397 (дата обращения: дд.мм.гг.). DOI: 10.17805/trudy.2017.1.6 